\title{
Judicial Supremacy, Judicial Power, and the Finality of Constitutional Rulings
}

\author{
Scott E. Lemieux
}

\begin{abstract}
It is widely assumed that the Supreme Court of the United States has established supremacy over contested constitutional questions, with the power to make final determinations of constitutional meaning. Since the 1960 s, most scholars have assumed that legislatures and courts are engaged in a power struggle in which countermajoritarian courts can assert their will over majoritarian legislatures. More recently, a new generation of scholarship has demonstrated that judicial power often expands as a result of the willful empowerment of the judiciary by actors in other branches. Most scholars working with the latter framework, however, do not dispute that the United States has a regime of judicial supremacy - they simply see the political empowerment of courts as an explanation for why judicial supremacy has emerged despite the initially weak position of the judiciary. I argue that the insights of the political empowerment literature should be pressed further. It makes little sense to use the general label "judicial supremacy" for a system in which judicial power remains dependent on choices made by other political actors. Examining several cases that are generally seen as canonical examples of assertions of judicial supremacy, I find that courts were unable to settle constitutional debates, and in addition often either were unable to achieve their policy aims or did not actually require other political actors to do anything. The logic of new empirical findings about the sources of judicial power should compel scholars to question whether aggressive assertions of supremacy in judicial opinions are in fact accurate descriptions of how judicial power functions in the United States.
\end{abstract}

\section{Judicial Supremacy and the Political Empowerment of Courts}

$\bigcirc$ ne question in Gibson and Caldeira's ${ }^{1}$ justly influential survey of public knowledge of the Supreme Court asks is do you happen to know who has the last say when there is a conflict over the meaning of the Constitution- the U.S. Supreme Court, the U.S. Congress, or the President. The "correct" answer

Scott E. Lemieux is Instructor in Political Science at the University of Washington (slemieux02@gmail.com). His research interests include public law, constitutional law, comparative law and institutions, and American politics. He has written or co-written articles for Perspectives on Politics, New Political Science, Polity, Studies in Law, Politics and Society, the Journal of Supreme Court History, the Maryland Law Review, and the American Journal of Comparative Law, and also contributes regularly to the The New Republic, The Week, and The Guardian. He wishes to thank Terri Perretti, Mark Graber, Julie Novkov, George Lovell, Jeff Dudas, Sarah Hampson, Mitch Pickerill, Tom Keck, Gerald Rosenberg, Jacob Levy, Chris Manfredi, the members of the SUNY Albany Public Law Workshop, and Jeffrey Isaac and the anonymous Perspectives on Politics reviewers for their immensely helpful comments on various drafts of this article. He also wishes to thank Xiaoye She for her editing assistance. to the question is "the Supreme Court." Respondents who did not choose the first answer were coded as answering erroneously, suggesting that the finality of Supreme Court interpretations of the Constitution is no longer even a point of reasonable dispute. The premises of this survey question represent the conventional understanding of judicial supremacy: when courts and other political actors disagree about what the Constitution means, the interpretation of the courts will prevail. "We live in a world of judicial supremacy," as Freidman and Delaney put it, "in which the Supreme Court appears to have the 'exclusive' power to determine the meaning of the Constitution, even with regard to the work of the coordinate branches of the national government."

An important body of scholarship, while generally accepting that judicial supremacy describes judicial power in the contemporary United States, has shown that this alleged supremacy is contingent and not an inevitable product of the Constitution. A number of studies have shown that the judiciary's increasing power has derived primarily, not from fixed constitutional powers or assertions of power in judicial opinions, but from the empowerment of courts by the elected branches. As a result, judicial power is both more fragile and more closely tied to the interests of political actors than is commonly assumed. Several of the most important and theoretically sophisticated works in this tradition have 
explicitly linked the political empowerment of the courts with the rise of judicial supremacy. Keith Whittington uses a wealth of historical detail to show that judicial supremacy has become entrenched because, regardless of where they are situated in "political time," presidents have often found judicial power useful in pursuing certain political and policy goals, although presidents who succeed in reconstructing the political order have generally presented challenges to judicial supremacy as well. ${ }^{3}$

The literature on the legislative empowerment of the courts provides a far more convincing explanation for the relative growth of judicial power than the traditional "counter-majoritarian framework," and a result also provides a superior basis for normative assessments of the legitimacy of judicial review. ${ }^{4}$ In the context of evaluating the apparent entrenchment of judicial supremacy, however, this scholarship produces its own puzzle. Given the convincing findings of these scholars that judicial review is largely a creation of elected officials, frequently serves the interests of elected officials, and is contingent on at least the acquiescence of elected officials to be maintained, the natural next question is to inquire in what sense such an institutional configuration represents a regime of "judicial supremacy" at all.

The logical implication of the findings of this body of work is that it is better to focus on judicial power rather than judicial supremacy. The concept of judicial supremacy carries with it implications about the finality and authority of judicial opinions, as well as the independence of the judiciary, that present a misleading picture of the actual functioning of judicial review. On the one hand, the judicial supremacy framework can overstate the power of the courts while erasing the extent to which constitutional commitments are enforced by other actors. As one scholar puts it, the "constitutional obsession with the federal judiciary unduly minimizes constitutional decision-making by elected officials and grossly exaggerates the independent role of the Supreme Court as a constitutional authority." The language of judicial supremacy inexorably suggests that the Supreme Court dominates the field of constitutional authority when in fact it shares the field with other institutional actors and groups and by no means always gets its way. ${ }^{6}$

The term judicial supremacy can be used in a variety of different ways, so it is important to distinguish between doctrinal, normative, and empirical uses of the term. There is no question the Supreme Court has, over time, been increasingly aggressive about asserting its supremacy in constitutional interpretation. This is an interesting phenomenon in itself, but given the self-serving nature of such claims they should not be taken at face value as descriptions of how constitutional norms get politically established and what these norms consist of. There is also a substantial literature addressing the question of whether judicial supremacy is desirable. While it is also of considerable interest, I leave aside this normative question. Instead, my focus is on the empirical questionthat is, whether judicial supremacy is the best way to describe how constitutional debates get settled. Most of my examples here will be drawn from the context of American politics, although parts of my analysis could be used to evaluate other constitutional systems as well.

My conclusion is that affixing the label judicial supremacy to American constitutionalism distorts the nature of judicial power in important ways. The implicit assumption that the constitutional vision of the judiciary generally triumphs is not empirically accurate. The substantial role that non-judicial actors play in creating constitutional norms and practices largely disappears. The judicial supremacy framework centers constitutional discourse on the courts, and this centering is frequently unjustified. Constitutional norms are generally established collaboratively, and it is not unusual for courts to play a merely coordinate role, a subordinate role, or no role at all.

Fundamentally, judicial supremacy is an incoherent concept that inaccurately describes the actual functioning of constitutional politics. The Supreme Court of the United States does not resolve every constitutional issue that arises in the United States and the Supreme Court is almost never acting alone when it appears to establish a new constitutional baseline. When justices declare laws unconstitutional they are almost always supported by some members of the governing majority on the front end (as elected officials, as well as groups allied with the governing coalition are responsible for generating constitutional arguments for courts to resolve) or the back end (as elected officials can prevent efforts to attack the decision or court through ordinary legislation). In short, shifting interbranch coalitions are best conceptualized as having the authority over constitutional meanings, and like governing coalitions established constitutional meanings tend to be impermanent.

To show that judicial supremacy is an inadequate means of assessing and characterizing judicial power, I first isolate some apparent underlying assumptions of the broader judicial supremacy one, in order to identify specific, concrete outcomes that would logically be associated with the label. I then examine some of the landmark cases most often associated with judicial supremacy. I conclude that in all of these cases judicial supremacy is an inadequate description of a more complex process. Even the most famous examples of judicial supremacy generally do not involve the courts clearing the constitutional field, but show more complex interactions between political actors. These cases strongly suggest that we need a different, less misleading way of describing how judicial power works. 


\section{The Components of Judicial Supremacy}

One crucial lesson of the political empowerment literature is that individual judicial nullifications of statutes do not necessarily represent a policy disagreement between judicial majorities and current legislative majorities. ${ }^{7}$ Apparent conflicts between the courts and the political branches may be false or ambiguous. To take the most obvious example, judges may nullify legislation produced by a legislative coalition that could no longer be re-assembled, ${ }^{8}$ or in some cases, legislation clearly opposed by current legislative majorities. ${ }^{9}$ It is also common for acts of judicial review to involve national majorities invalidating the policies of regional outliers. ${ }^{10}$ In addition, the literature has established that legislators generally have many more tools for reversing or mitigating the effects of even constitutional holdings than is generally supposed. In addition to the admittedly very burdensome Article $\mathrm{V}$ amendment process, elected officials can (and have) overcome or mitigated unfavorable constitutional rulings with actions such as noncompliance, jurisdictionstripping, pursuing alternative means to achieve similar policy results, and confirming new judicial personnel. ${ }^{11}$ For these reasons, it cannot simply be assumed that an act of judicial review that establishes a relatively durable policy outcome represents a successful imposition of will on the part of the judicial branch. Moreover, the fact that judiciaries owe most of their politically consequential powers to overt acts of legislative empowerment makes it very dangerous to assume that cases of false conflict are rare exceptions. It requires a careful case-by-case analysis to determine whether an individual act of judicial review represents a case of real or false conflict.

I have developed a framework that can be used to characterize particular acts of judicial review. ${ }^{12}$ Two categories represent scenarios in which judicial review does not reflect a clear conflict with the political branches, and hence a failure by Congress to take steps to reverse a decision cannot be assumed to reflect judicial supremacy:

- Minority vetoes are cases in which a judicial decision stands in opposition to a majority of members of Congress, but one of the potentially countermajoritarian veto points in the system (such as the presidential veto, the committee system, or the Senate filibuster) thwarts attempts to override or mitigate the effects of a judicial opinion. One important source of judicial power, then, comes from cases in which the support of a minority faction empowered by institutional features of the system allows a policy status quo established by the courts to prevail in the face of opposition from a majority of legislators. Such cases, however, are different than judicial decisions that are "final" because of judicial supremacy. Under slightly different political configurations, Congress might take action against the Court. It should be noted as well that under current institutional arrangements as few as 40 senators may have a de facto veto over legislation, and this veto power could be exercised on behalf of constitutional objections rejected by majorities of the House of Representatives and the Supreme Court as well as the president.

- Legislative Defaults are cases in which judicial opinions are sustained by a coalition of legislators who favor the policy established by the courts and legislators who are opposed or indifferent to the court's holding but gain political advantages from having the court take responsibility for resolving a contested issue. It is particularly important to remember that legislators do not in all cases attempt to maximize preferred policy outcomes. ${ }^{13}$ A Republican in a pro-choice district may find the displacement of the abortion issue onto the courts very convenient in political terms, allowing the legislator to signal opposition to legal abortion without threatening to reverse the status quo in a way that may alienate some pro-choice moderates whose votes might be decisive in a close election. Apparently "counter-majoritarian" decisions such as Roe may remain entrenched because many legislators find the new policy personally agreeable, and even legislators who oppose the opinion on policy or constitutional grounds may not make overruling the decision a high political priority since they derive sufficient political benefits from the courts' policy-making. ${ }^{14}$ Some cases, like Griswold v. Connecticut, may go beyond this and represent cases of legislative convergence, where the Court directly advances the policy preferences of a majority of legislators. The Supreme Court's invalidation of poll taxes following the explicit invitation of Congress is another likely example of legislative convergence. ${ }^{15}$

Of course, while the strong theoretical underpinnings of the political empowerment literature provide good reason to believe that cases of minority veto and legislative default are far from unusual, individual case studies cannot establish their precise frequency. It is important, therefore, to establish conditions that will enable scholars to identify cases of judicial supremacy. Since almost everyone would concede that judicial supremacy in its strongest possible form-the Court being able to impose authoritative constitutional interpretations in a manner that preempts any future political conflict-is unrealistic, it is necessary to break down judicial supremacy into its core components. These five sub-categories derive from what I take to be the most crucial premise of judicial supremacy: that judicial interpretations of the Constitution, especially when issued by the Supreme Court, are in some meaningful sense "final." 
The Supreme Court resolves all or at least most of the constitutional controversies that arise in the United States. One potential implication of judicial supremacy is that constitutional controversies are in the vast majority of cases resolved by the courts. But at a minimum, there have certainly been periods in which major controversies were largely resolved outside the courts. The constitutionality of congressional spending to fund internal improvements before the Civil War, for example, was determined almost entirely by Congress and the executive branch. The expansion and contraction of national power to prohibit the distribution of alcohol was accomplished through constitutional amendments and subsequent legislative and executive enforcement, not the courts. ${ }^{16}$ If major constitutional questions are still being decided with minimal or no intervention by the courts, this is at least a major limitation on the value of the judicial supremacy label.

The Supreme Court largely performs solos when resolving those constitutional controversies and is not substantially assisted by other political actors. The concept of judicial supremacy would seem to imply a zero-sum struggle for power in which the court is able to impose its constitutional vision on other actors. When constitutional controversies are resolved by the courts acting in collaboration with political actors who control relevant veto points, share the court's constitutional or political vision, and whose support is crucial for the court's decision being effective, judicial supremacy is not an obviously useful label. Judicial power may certainly be playing an important role in resolving such controversies, but "supremacy" is problematic as a description for cases in which allies in various institutions each make crucial contributions. If a constitutional ruling by the courts requires not merely acquiescence but substantial action by other political actors who share the values of the court, it's difficult to argue that the courts are "supreme" over the other institutions. ${ }^{17}$

Judicial supremacy is not a useful way of describing cases in which the Court advances policies preferred by powerful political elites. To the extent that exercises of judicial power reflect collaboration between the branches, judicial supremacy is not an adequate description of the interbranch relationship. Similarly, if attempts by Congress to reverse or mitigate the effects of judicial rulings are thwarted by the procedural rules of established by one of both house of Congress or by the bicameral structure of the legislature, judicial supremacy cannot be considered the key factor in allowing the judiciary to establish policy. Institutional rules that are not fixed by the Constitution can certainly increase effective judicial power, but they do not create a context in which judicial decisions are final, both because veto points can be overcome and the rules themselves are contingent. Focusing on judicial power rather than supremacy better reflects this contingency. If judicial interpretations of the Constitution are "supreme," it is not clear why they are more likely to prevail when there is divided government or a government controlled by factions sympathetic to the constitutional views of the Court.

The Supreme Court is willing to resolve constitutional controversies even when the Supreme Court's opinion disagrees sharply with the constitutional vision of the dominant national coalition. In a regime of judicial supremacy, one would expect the courts to be willing to impose a contrary constitutional vision even on a national governing coalition that doesn't share it. Conversely, if the courts are rarely willing to directly challenge a dominant governing regime, this raises questions about the value of the judicial supremacy label. If courts are generally only willing to overturn the judgments of political actors if they are confident they will have substantial support from the dominant governing coalition this suggests that judicial power is more collaborative than the judicial supremacy description plainly implies. The tendency of the Supreme Court to invalidate policies that are regional outliers ${ }^{18}$ is an important power, but it reflects federal supremacy more than judicial supremacy. Congress also has the power to preempt the policies established by state governments, sometimes in collaboration with the courts. $^{19}$

Governing officials routinely implement Supreme Court decisions with which they disagree. In a regime of judicial supremacy it is reasonable to assume that judicial directives will generally be enforced by other state actors. For example, the Supreme Court's ruling in Engle $v$. Vitale $^{20}$ - that voluntary teacher-led prayers in public schools are unconstitutional-has never been challenged by Congress or been overruled by a future Supreme Court; this does not make the case a good example of judicial supremacy if the decision was widely ignored by local administrators. And, in fact, multiple studies have found a substantial amount of noncompliance with respect to the Court's school prayer decisions, in both the short-term and long-term. ${ }^{21}$ Judicial supremacy implies a substantive capacity to set constitutional norms, not merely the ability to issue formal constitutional pronouncements that are unable to alter actual social practices.

Governing officials routinely act on the basis of constitutional principles announced by the Supreme Court with which they disagree, and Supreme Court constitutional rulings are strongly privileged in subsequent deliberations. Another element of judicial supremacy is the extent to which other actors generally respect judicial interpretations of the Constitution as being authoritative. We cannot reasonably expect judicial opinions to eliminate alternative constitutional meanings entirely. But if judicial supremacy accurately describes American constitutionalism we would at least expect judicial interpretations of the Constitution to enjoy 
a privileged status among both governing elites and the public. In a regime of judicial supremacy, conflicts over constitutional meaning should be much more intense before judicial rulings are issued than after the fact. To the extent that important political actors or substantial segments of the public remain committed to constitutional understandings inconsistent with those announced by courts, the extent to which a constitutional regime is genuinely characterized by judicial supremacy becomes more dubious. Even those who believe that judicial supremacy has now effectively been entrenched in the United States, for example, generally see Andrew Jackson's refusal to accept the Supreme Court's still-controlling analysis of federal power announced in McCulloch $v$. Maryland $^{22}$ in his message announcing the veto of the re-chartering the National Bank as a rejection of judicial supremacy. $^{23}$

The constitutional controversy over Jackson's bank veto can also be used to illustrate an important conceptual point. What looks like "judicial" supremacy may simply be the product of the high veto-point of the American institutional framework which generally errs on the side of inaction. Had the Supreme Court found the Affordable Care Act unconstitutional, this would have immediately led to assertions that judicial supremacy had been taken to new heights by the Roberts Court. Had the final Senate vote on the ACA happened a few months after it did, however, 41 Republicans in the Senate could have stopped legislation from passing based on constitutional objections. ${ }^{24}$ In that case, the statute would not have been enacted even though a majority of House of Representatives, a majority of the Supreme Court, and the recently elected president all believed that the proposed law was constitutional. The constitutional views of the minority party in the Senate would have prevailed for the foreseeable future, but nonetheless, most scholars would not describe American constitutionalism as a system of "Senate minoritarian supremacy." Similarly, in a scenario (such as Jackson's national bank veto) where the president vetoes a bill as unconstitutional while a majority of the Supreme Court believes it to be constitutional, that the president's view prevails does not mean that the American system is one of "presidential supremacy." But the argument cuts both ways. In the Madisonian framework, supreme constitutional authority over a given issue in at least some cases resides in the institution that says "no" as opposed to the courts. If the Court believes legislation is constitutional but the president does not and vetoes it on that basis, the president's view prevails, a serious anomaly for assertions of judicial supremacy.

These specific manifestations of judicial supremacy are meant to act more as suggestive heuristics than as ironclad tests. It is certainly possible that a regime can fairly be described as characterized by judicial supremacy without meeting all of these conditions in full. Gaps in enforcement are endemic, for example, and do not necessarily translate into a general lack of institutional authority, and the centrality of conflict to politics ${ }^{25}$ makes it unlikely that judicial holdings on contested constitutional issues will entirely resolve the underlying controversy. Still, to the extent that judicial interpretations of the Constitution substantially fail to establish authority in these ways (especially in more than one respect), the value of using the judicial supremacy label to successfully characterize the political and constitutional relationships being analyzed becomes increasingly dubious. Rather than building one qualification after another into the concept, it seems preferable to stop assuming judicial supremacy and simply focus on judicial power instead.

\section{Do the Canonical Cases of Judicial Authority Actually Reflect Judicial Supremacy?}

\section{Cases Where the Judiciary Is Clearly Not Supreme}

One means of attacking the concept of judicial supremacy would be to detail well-worn examples of major public officials repudiating important judicial rulings, such as Andrew Jackson's aforementioned bank veto message and unwillingness to protect the rights of native Americans against state governments; Lincoln's claim that Dred Scott could bind the parties of the litigation but did not immediately settle the broader constitutional questions it addressed; ${ }^{26}$ or the Reagan administration's challenges to judicial supremacy, especially with respect to Roe v. Wade. ${ }^{27}$ Because even many of those who believe that judicial supremacy has become entrenched in American constitutionalism - whether generally supportive or critical of the development-believe that the development was a lengthy struggle, ${ }^{28}$ such exceptions can reasonably be dismissed as historical anachronisms or anomalies. Instead, I will examine some of the cases that are most often discussed when scholars and court observers describe what they believe to be a regime of judicial supremacy in the United States. ${ }^{29}$ I therefore consider some canonical illustrations of judicial supremacy: the Court's landmarkafter-the-fact first ruling of a federal statute unconstitutional in Marbury v. Madison, the Court's most famous unequivocal assertion of judicial supremacy in response to the Little Rock school desegregation crisis, the Court's apparent settlement of the contested 2000 presidential election, and the Rehnquist Court's invalidation of the Religious Freedom Restoration Act.

As with the use of "tough cases" in comparative politics, by using the cases that would seem most obviously inconsistent with my argument that the United States does not have a robust regime of judicial supremacy I can provide a useful test of my thesis. This is not to say that any selection of cases can be definitive-I cannot deny the potential existence of cases that would clearly satisfy all three of the criteria outlined here, and any conclusions 
drawn from a limited set of cases must by necessity be considered tentative, even if inferences drawn from tough cases are more robust than those drawn from cases everyone recognizes to be supportive of my argument.

But it should also be noted the choice to focus on hard cases also leaves out important evidence in favor of skepticism about the material existence of judicial supremacy in the United States. For example, the ongoing willingness of many members of Congress to challenge the constitutional rulings of the Court ${ }^{30}$ and to make independent constitutional judgments ${ }^{31}$ raises serious questions about the reality of judicial supremacy, particularly with respect to the Court's normative authority. More importantly, by definition these cases exclude one obvious set of cases that the judicial supremacy label cannot adequately account for: cases where courts remain entirely or almost entirely silent during struggles to establish new constitutional norms. The constitutional norm that Congress can delegate the decision to go to war to the executive branch, and a formal declaration of war is unnecessary for even major military action, for example, has become entrenched with the courts remaining almost entirely on the sidelines. ${ }^{32}$

\section{Marbury v. Madison: "A Minor Episode in American Constitutional Development"}

Though little-noticed for most of the nineteenth century, John Marshall's opinion in Marbury v. Madison has been transformed into the fountainhead of judicial review ${ }^{33}$ and, for many, judicial supremacy. Many scholars consider Marbury to be not just symbolically important but an important causal agent explaining the emergence of strong judicial review in the United States. Several recent books about the Supreme Court written for general audiences reflect the ongoing assumed importance of Marbury. Two books about Marbury, one generally laudatory of Marshall's opinion ${ }^{34}$ and one generally critical, ${ }^{35}$ each assume that the decision led directly to a regime of judicial supremacy in the United States. James MacGregor Burns's critique of what he assumes to be a regime of judicial supremacy asserts that "the Supreme Court ... acquired its power through a brilliant coup at the hands of Chief Justice John Marshall in 1803" and that Marshall in Marbury "laid the basis for a power of judicial review so absolute and sweeping that it would eventually create a supremacy of the Supreme Court over American government." 36 The perceived importance of Marbury has become such that Marshall's opinion is displayed under glass in the National Archives next to the Constitution, the Declaration of Independence, and the Bill of Rights. ${ }^{37}$

The literature on the political empowerment of the courts has conclusively demonstrated, however, that the relative inattention given to the case prior to the twentieth century was a more accurate reflection of its actual impact on the eventual entrenchment of judicial power. Far from a case that led directly and inexorably to a politically consequential form of judicial review, let alone judicial supremacy, Marbury was "a minor episode in American constitutional development." ${ }^{\text {"3 }}$ The opinion made unoriginal arguments in favor of judicial review, and overruled a trivial statutory provision in order to avoid issuing an order that Chief Justice Marshall assumed would be ignored by the Jefferson administration. The case was not cited in a defense of judicial review by the Supreme Court until the already well-established practice attracted political controversy in the late nineteenth century. ${ }^{39}$ Even more important, since virtually everyone acknowledges that Marshall lost the short-term power struggle with the Jefferson administration, is the fact that subsequent to Marbury the Marshall Court never overruled a statue clearly favored by the majority governing coalition of the day, even though the dominant political elites through much of Marshall's tenure had a constitutional vision that was in substantial tension with Marshall's own. ${ }^{40}$

This revisionist scholarship leaves no question that Marbury itself cannot remotely satisfy any of the three criteria for establishing judicial independence. The Court avoided a power confrontation with the other branches (and hence left nothing to be enforced), and the decision carried little to no normative weight at the time it was handed down. As already noted, Marshall's vision of the Constitution was largely rejected by the Jacksonian Democrats who dominated antebellum American politics. In the short term, Marbury did not even establish a politically important form of judicial review - let alone judicial supremacy - with respect to the federal government. Instead, the case represented the first in a series of "strategic judicial retreats in the face of threats by executive or state power." ${ }^{41}$ The fact that Marshall's opinion was mostly ignored by the federal courts until the late nineteenth century also makes implausible the claims that it created a crucial foundation for judicial supremacy. ${ }^{42}$ This is particularly true given that the logic of Marshall's justification of judicial review is compatible with departmentalist as well as supremacist interpretations. ${ }^{43}$ As Whittington observes, "it is the purest bootstrapping to imagine that [Marbury] established judicial supremacy as a political practice." 44

One curious aspect of Marbury, however, is that the conventional interpretation of the case does not really dispute that the case was "a masterwork of indirection" 45 decided from a position of extreme weakness. The assumption that the United States is now characterized by a regime of judicial supremacy is so strong that it is often projected backwards onto Marbury, although virtually all accounts of Marshall's actions contradict the general narrative. And, yet, the recurring tendency of the Supreme Court to use Marshall's technique of steering clear of political opponents when announcing new doctrines ${ }^{46}$ should in itself lead to questions about how 
strongly entrenched judicial supremacy really is. A particularly striking example is Goldstone, ${ }^{47}$ who (like the revisionists) extensively examines Stuart $v$. Laird, $^{48}$ the critical ruling handed down a week after Marbury. In that relatively neglected case, the Court acquiesced in the repeal of the Judiciary Act of 1801 although a majority of the Court almost certainly believed the statute to be unconstitutional. Most importantly, the repeal of the Judiciary Act eliminated the newly created layer of circuit courts, which both eliminated a substantial number of judges formally entitled to life tenure and compelled Supreme Court justices to once again engage in the arduous practice of circuit-riding. ${ }^{49}$ Not merely abstract issues of constitutional principle but the physical and mental well-being of the justices were at stake-and yet they deferred to a statute that was contrary to both. Goldtsone, then, fully recognizes the Marshall Court's nearly complete capitulation to the Jeffersonians, but these important insights essentially fall out of his central narrative, which takes as a given that Marbury established judicial supremacy nearly out of whole cloth.

It is quite clear that Marbury in no way created, or was even a significant causal factor leading to, the increase of judicial power in the twentieth century (leaving aside the question of whether this can be accurately characterized as “judicial supremacy”). If judicial supremacy was indeed established in the United States, it was at least a century after and caused by events almost entirely independent of Chief Justice Marshall's famous opinion. Marbury was the product of a Court unwilling to challenge a federal governing authority head-on, which the assumption of judicial supremacy assumes courts will be willing to do. The persistence of the myth of Marbury in the teeth of evidence that is largely contained even within conventional accounts, however, provides a valuable lesson about taking assumptions about the establishment of judicial supremacy for granted.

\section{Cooper v. Aaron: The Twentieth- Century Marbury}

Just as Marbury is the case most associated with the entrenchment of judicial review, Cooper $v$. Aaron ${ }^{50}$ is the case most associated with judicial supremacy. In the face of open defiance of its landmark Brown ruling by the Little Rock school board and the Arkansas government, the Court's unanimous and jointly-written opinion famously (and misleadingly) ${ }^{51}$ asserted that Marbury "declared the basic principle that the federal judiciary is supreme in the exposition of the law of the Constitution, and that principle has ever since been respected by this Court and the Country as a permanent and indispensable feature of our constitutional system." Because of the Court's famous assertion of its alleged long-standing supremacy in constitutional interpretation, the case has become strongly identified with the perceived twentieth-century establishment of judicial supremacy. But Cooper can be compared to Marbury in another way as well: even according to the conventional assessment of the case, there is an obvious tension between the importance claimed for the case and the actual power of the Court that issued the ruling.

While Cooper $v$. Aaron is a complex case, it ultimately reveals very significant limitations of judicial authority that are plainly inconsistent with the Court's own assertions of interpretative supremacy. The case does present a real policy conflict, although this conflict is complicated by federalism. The populations most directly affected by Brown v. Board of Education were strongly opposed to desegregation rulings from the federal courts, but Earl Warren and his brethren had at least some measure of support from the president and Congress, as well as the majority support of national public opinion. ${ }^{52}$

In terms of enforcement and normative authority, however, it is difficult to see Cooper as a compelling example of judicial supremacy, let alone as a definitive one. While Eisenhower reluctantly agreed to intervene to defend the Court during the Little Rock crisis, the Deep South remained as defiant as ever. The "Little Rock scenario of violence was reenacted in New Orleans" despite the Supreme Court's admonitions about the importance of the rule of law. ${ }^{53}$ Progress on desegregation in the Deep South remained almost non-existent until the passage of the Civil Rights Act, ${ }^{54}$ and to the extent that the Supreme Court's actions had a causal impact on Congress' historic intervention it was the resistance generated by Brown rather than a widespread acceptance of judicial authority that was most important. ${ }^{55}$ If the concept of judicial supremacy entails the ability of courts to generate at least a substantial measure of compliance from the public and crucial public officials who disagree with the Court on the policy merits, Cooper is better evidence for the lack of judicial supremacy than for its existence.

With respect to the Court's normative authority-its ability to set an interpretive baseline that is privileged going forward-the picture is similar. Cooper $v$. Aaron "convinced" those who already accepted the Court's authority and agreed with its substantive rulings on desegregation and very few others. Arkansas governor Orval Faubus and the signers of the Southern Manifesto 56 would be certainly surprised to learn that judicial supremacy had "been respected by this Court and the Country as a permanent and indispensable feature of our constitutional system." Cooper also did nothing to quell the increasing radicalization of Southern politics, in which essentially no candidate for state office could be too opposed to desegregation for the electorates of their states. ${ }^{57}$ Cooper, like Brown, has ultimately gained broader acceptance-but this has more to do with the Court being on the right side of long-term political history than to its ability to impose constitutional meanings on other 
political and social actors. ${ }^{58}$ Moreover, the Court itself did little to enforce desegregation again until the political climate had become significantly more favorable. ${ }^{59}$ Contemporaneously, Cooper left the existing constitutional conflict over Southern apartheid more or less as it found it, the Court's somewhat desperate claims of judicial supremacy notwithstanding.

As is the case with Marbury, it is not uncommon for conventional and revisionist assessments of judicial authority to co-exist within the same argument. Carptenter's extensive discussion of resistance to the Court's intervention into the Little Rock crisis is followed by the assertion that "Cooper v. Aaron did not invent judicial supremacy; it confirmed it." ${ }^{60}$ Just as Marshall acted strategically to avoid an unwinnable conflict the resistance to Brown on the part of the Jim Crow not only persisted but intensified for a significant length of time after the Court's assertion of constitutional hegemony is no secret. Just as Marbury announced the power of judicial review before it had been established as a politically consequential practice, the Court's opinion in Cooper did not reflect any actual ability to pre-empt contrary constitutional meanings. And while it is possible that Cooper could foreshadow the establishment of a more robust judicial supremacy just as Marbury foreshadowed the ultimate establishment of a more robust judicial review, the actual practice of judicial supremacy has to be produced by subsequent and largely independent actions if it has indeed been established.

\section{City of Boerne v. Flores: The Court vs. Congress}

A much stronger case that a politically consequential judicial supremacy has been established in the United States can be seen in the Court's 1997 invalidation of the Religious Freedom Restoration Act (RFRA) of 1993, at least as it applied to the Supreme Court. ${ }^{61}$ This statute was a direct challenge to the Supreme Court's interpretation of the Constitution. In a controversial 1990 ruling, the Court significantly narrowed its previous interpretation of the free-exercise clause of the First Amendment, ${ }^{62}$ holding that generally applicable state regulations of conduct that burdened religious minorities were constitutional unless they were directly targeted at religious practices. In response, Congress sought to restore the Court's previous, more expansive interpretive standard, ${ }^{63}$ citing its ability ${ }^{64}$ to enforce the provisions of the Fourteenth Amendment (and hence the First Amendment as it applied to the states). Employment Division v. Smith generated significant opposition from a strange-bedfellows coalition of evangelical conservatives and civil libertarians, and as a result RFRA passed the Senate 97-3 and did not receive a single "nay" vote in the House of Representatives. ${ }^{65}$

A majority of the Court, speaking through Justice Anthony Kennedy, was unimpressed by the congressional consensus. The Rehnquist Court did Cooper v. Aaron one better, insisting on its supremacy in constitutional interpretation not against a minority acting in defiance of judicial orders but against overwhelming congressional majorities acting through valid procedures. According to Kennedy, the power given to Congress "to enforce" the provisions of the Fourteenth Amendment did not entail the power to determine what constituted a constitutional violation. Were it not so, what Congress would be enforcing would no longer be, in any meaningful sense, the provisions of the Fourteenth Amendment. According to Kennedy,

If Congress could define its own powers by altering the Fourteenth Amendment's meaning, no longer would the Constitution be "superior paramount law, unchangeable by ordinary means." It would be "on a level with ordinary legislative acts, and, like other acts, ... a alterable when the legislature shall please to alter it" ... . Shifting legislative majorities could change the Constitution and effectively circumvent the difficult and detailed amendment process contained in Article $\mathrm{V}$.

The crucial move here is Kennedy's assumption that in offering a different interpretation of the Fourteenth Amendment Congress was "altering" the meaning of the Constitution, which we must therefore imply is exclusively determined by the Court. While not as aggressive in its language as Cooper v. Aaron, the assertion of the Supreme Court's supremacy in constitutional interpretation is equally clear. As Lucas Powe characterizes the Court's logic, "Congress should know its place and recognize judicial supremacy, and the Court should keep Congress subordinate."

This case is potentially important not only because the Court seemed "to advance a very strong version of judicial supremacy." ${ }^{67}$ City of Boerne was part of a series of cases ${ }^{68}$ that asserted the supremacy of judicial interpretations of the Constitution while arguably presenting judicial review at its most normatively unattractive. While a principal justification for judicial review is the potential for the more politically insulated branch to protect minorities underrepresented or excluded from the political process, ${ }^{69}$ the Rehnquist Court repeatedly held that Congress could not provide more protection for the rights of minorities than the Court determined was necessary. ${ }^{70}$ The monopoly on constitutional interpretation claimed by the Court in these cases pertaining to Congress' ability to enforce the Fourteenth Amendment could undermine a crucial justification for strong-form judicial review, making the prospect of judicial supremacy considerably more troubling.

Considered more carefully, however, there are some important problems with seeing City of Boerne as establishing (rather than asserting) judicial supremacy. There is, first of all, an obvious normative authority problem. In a robust regime of judicial supremacy, it seems unlikely that a Supreme Court holding in a constitutional case would be rejected just three years later by a nearly unanimous vote in both houses of Congress. The passage of RFRA 
demonstrates forcefully that Congress has been unwilling to fully cede constitutional interpretative authority to the Court. While it is unrealistic to expect judicial holdings to generate an immediate consensus even in a robust regime of judicial supremacy, or for judicial rulings to always be respected as politics changes over time, a near-total rejection by federal elected officials in the immediate aftermath of a decision is another matter.

Perhaps more importantly, it should be noted that the Court's ruling did not force either state or federal governments to do anything. If the cross-regional and cross-party consensus reflected in the nearly unanimous passage of RFRA is real, the policy impact of City of Boerne should be relatively small. After all, both state and federal governments remain free to interpret the free-exercise clause more broadly than the floor established by the Supreme Court requires. In addition, RFRA remained in force as applied to Congress and the federal executive branch unless a future statute explicitly said otherwise, a fact that has already proven politically consequential. In a controversial recent decision the Supreme Court interpreted RFRA as requiring the Obama administration to exclude religious employers from a regulatory requirement to provide contraception in employer-provided health care plans. ${ }^{71}$ And it did so even though the regulation is almost certainly constitutional as long as Employment Division v. Smith remains good law.

At most, City of Boerne would permit a few state outliers to depart from the national consensus. And nor would the decision necessarily prevent the federal government from exercising its authority over the states in any case. To the extent that Congress was genuinely worried about state governments violating religious liberties because of what it viewed as the Supreme Court's unreasonably narrow reading of the free-exercise clause, it could for example achieve similar ends by simply attaching requirements for the protection of religious minorities to federal grants. ${ }^{72}$

The apparent constitutional checkmate announced by the Court in City of Boerne, then, is less decisive than it appears on the surface. Congress's response to Employment Division v. Smith demonstrates an ongoing willingness and ability to independently interpret the Constitution, and the Court's superficial reclaiming of authority in City of Boerne did little to prevent Congress and nothing to prevent state governments from advancing a more expansive vision of the free-exercise clause if they so desired. What seems like the Rehnquist Court's most forceful statement of judicial supremacy is reflective of an entrenched practice of judicial supremacy only if the concept is defined very narrowly.

\section{Bush v. Gore: The Ultimate Political Power?}

To the extent that City of Boerne is not the dominant symbol of what is widely perceived as the aggressive assertion of judicial supremacy by the Rehnquist Court, it is because it has been displaced by the Court's considerably more famous resolution of the 2000 presidential election. ${ }^{73}$ The Court's ending of the fiercely disputed 2000 contest between George W. Bush and Al Gore in a 5-4 decision subject to serious questions about its plausibility and coherence ${ }^{74}$ symbolized to many a "new age of conservative judicial supremacy." ${ }^{\text {" }}$ And, indeed, it is hard to conceive of a better example of judicial supremacy than using constitutional interpretation to determine the winner of a presidential election. To Hirschl, Bush v. Gore provides a definitive example of the increasing global trend towards "juristocracy." "76 Particularly disturbing, as noted by Balkin and Levinson, ${ }^{77}$ is the fact that by resolving the 2000 election in favor of the candidate more ideologically congenial to the majority the Court seemed to ensure that their own constitutional vision would retain a majority on the Court (and gain more power throughout the federal courts.) In this sense, the apparent exercise of judicial supremacy of Bush $v$. Gore created a self-perpetuating constitutional hegemony. In the abstract, it is hard to imagine a better example of judicial supremacy than a case that allowed the Supreme Court to determine the next president, and hence to indirectly control the direction of the federal courts as well.

As with City of Boerne, however, the extent to which Bush v. Gore exemplifies judicial supremacy becomes more questionable when the political context and consequences of the decision are evaluated more carefully. The typical argument that the Court "decided" the winner of the 2000 election is somewhat misleading as, given the configuration of political forces, Bush was nearly certain to become president even had the Court refused to hear the case. Although "a majority of people who cast votes in the 2000 Florida Presidential Elections thought they were voting for Gore," given Republican control of the two relevant decisionmaking bodies, Bush was virtually certain to become president one way or another. ${ }^{78}$ The Florida legislature could have sent a pro-Bush set of electors however a recount turned out, and it was Congress that would determine which set of electors was legitimate. Both of these bodies were controlled by Bush supporters who were not about to second-guess the Supreme Court's decision. This is not to say that the Court's decision had no effect. It is plausible to assume (albeit very difficult to prove) that the Court's decision had an important effect in terms of legitimating Bush's presidency. It is plausible, although not certain, that had he came to office through a party-line congressional vote Bush may have had less success getting congressional and public support for his first-term agenda. But saying the Court might have created somewhat more favorable political conditions for Bush is quite different from the stronger claim that it handed Bush the presidency and hence perpetuated its own constitutional vision.

Moreover, Republican control of the key post-election decision-making bodies largely removes a key component of an act reflecting judicial supremacy: a genuine 
constitutional conflict between branches of government. The Court did not so much impose a constitutional vision on antagonistic elected branches, as follow its typical practice of siding with the most powerful governing elites in a political dispute. The Court's five-person majority "knew that an intervention would not be met by any institutional resistance or short-term political retribution." 79 Had the Court decided the case in favor of Gore and prevailed, this would have been a genuine example of judicial supremacy (although it seems very unlikely in such a case that Republican political actors and their base of mass support would have acquiesced without a very protracted struggle). The decision the Court made, however, reflects collaboration with governing majorities rather than the definitive resolution of a constitutional dispute. The Supreme Court rarely performs solos, in other words, and Bush v. Gore is not an exception to this rule. And from a standpoint of the Court's normative authority, the picture is similar. Virtually nobody already predisposed to not favor Bush's election supported the Court's action, and its opinions were subjected to a large amount of vituperative criticism. Conversely, those predisposed to like the Court's resolution of the case thought better of the Court after the ruling. ${ }^{80}$ The decision did not on balance damage the reputation of the Court, but it did not persuade skeptics either.

Bush v. Gore undoubtedly raises many interesting questions about constitutional interpretation and the legitimacy of judicial power. But as a potential example of judicial supremacy, it is neither here nor there. The case did not resolve a constitutional dispute that would command significant interest outside of the unusual political context, and the Court's resolution neither required a direct conflict with a hostile political body nor commanded normative authority among people who disagreed with the outcome of the case. This is not to say that the role of the Court was unimportant: it is entirely possible that the perceived legitimacy of the Supreme Court caused Gore to react with more equanimity than he would have had the election been resolved by other institutional actors. But Gore had no effective mechanism to respond, not because the Constitution failed to provide one, but because his political opponents controlled the key non-judicial decision-making bodies. It is therefore misleading to suggest that the Court unilaterally resolved the 2000 election. Superficially, Bush v. Gore seems like a particularly powerful example of the entrenchment of judicial supremacy in the United States. But upon a more careful examination it provides a better example of the importance of interbranch collaboration than a reflection of judicial supremacy.

\section{Conclusion: Rethinking Judicial Power}

The theoretical weaknesses of the judicial supremacy assumption and the canonical cases most often used as illustrations both demonstrate good reasons to abandon the assumption. "Judicial supremacy" is simply inadequate to describe how judicial power functions in practice. Assuming that American constitutionalism is characterized by judicial supremacy leads to a number of distortions: a dismissal of independent constitutional interpretation outside the courts, exaggerating conflict and minimizing cooperation (explicit and tacit) between the branches, and allowing legislators to nullify accountability for issues that remain much more in their control than is sometimes assumed. While both cases are subject to criticism on a number of plausible grounds, City of Boerne did not prevent state or federal legislators from protecting an expansive vision of religious free exercise, and Bush $v$. Gore notwithstanding, the Democratic Party lost the 2000 election (both before and after the fact) mostly outside of the courts. To attribute royal authority to the courts relieves other political actors of their proper responsibility for these outcomes.

The severe limitations of the judicial supremacy framework can be seen by examining several different civil rights cases. First, consider the controversial recent Supreme Court decision Shelby County v. Holder, ${ }^{81}$ which struck down the formula Congress had used to determine which states would have to "preclear" changes to their voting laws with the Department of Justice under the Voting Rights Act. On its face, the decision fits perfectly into a judicial supremacy framework. The Voting Rights Act was re-authorized in 2006 by huge bipartisan majorities - 98-0 in the Senate, 390-33 in the House of Representatives-and signed into law by a Republican president. And yet the Supreme Court struck down one of its most important provisions, apparently imposing its will contrary to the near-consensus will of the nation's elected representatives.

The political reality, however, is considerably more complex than the story the judicial supremacy assumption tells us. When the Supreme Court struck down the particular preclearance formula contained in Section 4 of the Voting Rights Act as exceeding the powers granted to Congress by the Constitution, it did not hold that preclearance was inherently unconstitutional, and Chief Justice Roberts's opinion for the Court implied that a formula updated to current conditions by Congress could be constitutional. Roberts had also warned about the possibility that a preclearance formula that was not updated might be struck down in Northwest Austin v. Holder. ${ }^{82}$ And yet Congress did not act after the first warning, and as of 2016 has not acted and shows no signs of acting to update the formula. This inaction strongly suggests that Shelby County did not necessarily contradict the policy preferences of many legislators from the party that in 2016 controls both houses of Congress. Many Republican legislators, for example, might support the Voting Rights Act as a whole but oppose the preclearance 
provision, which has generated substantial Republican opposition going back to the Nixon administration. ${ }^{83}$ Whatever the reasons for congressional inaction, though, it is highly misleading to suggest that the Supreme Court is the sole reason that no states currently have to preclear changes to their voting laws.

Civil rights in the nineteenth century provides an even stronger example. Virtually every high school student leans about Plessy v. Ferguson, ${ }^{84}$ which has come to symbolize the institution of segregation in the South after the Civil War. But the Reconstruction Congress did not see the courts as the institution central to enforcing civil rights. All three of the Civil War amendments gave Congress the power to enforce the amendments. Even more strikingly, Section 2 of the Fourteenth Amendment did not merely empower but required Congress to reduce the congressional representation of states that disenfranchised freedmen. ${ }^{85}$ Congress nonetheless refused to enforce the Fourteenth Amendment through Section 2.

This failure of constitutional responsibility on the part of Congress is much less well known than Plessy, largely because the story of civil rights between Reconstruction and the Civil Rights Act is largely told through the lens of Supreme Court opinions. This emphasis cannot easily be justified on grounds that judicial decisions were the crucial causal driver of Jim Crow. As Michael Klarman points out, Plessy was at best a minor factor in the establishment of segregation, and had the case come out the other way it would almost certainly have been ignored by Southern states and it is clear the executive and legislative branches of the federal government would not have used coercion to enforce it. ${ }^{86}$ The language of judicial supremacy tends to obfuscate reality in cases where the actions (or inactions) of legislative and executive branch are more crucial to establishing constitutional practices than the action or inaction of the judiciary.

The assumption that judicial supremacy tends to mask major congressional failures on civil rights as Jim Crow was being entrenched. Conversely, during the era in which Jim Crow was being dismantled, the judicial supremacy assumption implicitly misdescribes a collaborative effort as a zero-sum conflict. As the earlier discussion of Cooper v. Aaron showed, when acting alone the courts could accomplish very little to advance civil rights in the most hostile jurisdictions. But this does not mean that the courts were irrelevant to the dismantling of segregation, either. The Civil Rights Act and Voting Right Act both made substantial use of the federal courts, assuming that litigation initiated by both the federal government and private groups and individuals was crucial to enforcing congressional aims. The dismantling of Jim Crow was a collaborative enterprise in which both legislatures and courts made a distinctive contribution. $^{87}$ The judicial supremacy framework, however, does not properly account for these collaborative and contingent sources of judicial authority.
And this is the central problem with the judicial supremacy assumption: it prejudges questions of responsibility for constitutional (and related policy) outcomes with a framework that oversimplifies and distorts processes that are in many or even most cases much more complex. It should be emphasized that the inadequacy of the judicial supremacy as a descriptor should not be taken as a denial that there has been an increase in judicial power. Authority delegated to the courts and exercised with significant constraints is still an important form of power, just like power delegated to and exercised with significant constraints by the executive branch. The Court was in substantial measure serving the political interests of many political actors when it issued major rulings about abortion, but it could have resolved the cases within a significant range of potential outcomes without provoking retaliation. ${ }^{88}$

Modern partisan configurations combined with the high number of veto points in the American system expand the range of the courts to impose their interpretations of both constitutional and statutory provisions, as the judicial interpretation will stand up so long as the Court's friends command at least one of the veto points. ${ }^{89}$ The ability to set a policy baseline in some cases is an important power, not just with respect to the constitutional cases that the judicial supremacy assumption is primarily concerned with, but in statutory interpretation cases as well. Had, for example, the Supreme Court ruled in King v. Burwell that health insurance exchanges established by the federal government could not make tax credits available, this almost certainly would have established policy for many years even if Congress can theoretically change the law in response to the Supreme Court at any time. Contingent and collaborative powerthe most common kind in a Madisonian framework-is still power. Moving beyond the assumption of judicial supremacy should not result it concealing the power of the courts, but instead should help to reveal the responsibility shared by other actors in establishing and challenging constitutional norms and practices.

\section{Notes}

1 Gibson and Caldeira 2009, 29.

2 Freidman and Delaney 2011, 102.

3 Whittington 2007. See also, for example, Hirschl 2004; Powe 2009.

4 I elaborate further on this argument in Lemieux and Watkins 2008, providing examples of scholarship that uses the "counter-majoritarian framework" and why this is theoretically and empirically problematic.

5 Graber 2013, 102.

6 For more on this point, see Fisher 1993.

7 See esp. Graber 1993; Lovell 2004, ch.1.

8 For examples, see Tushnet 2006.

9 The retrospective nullification of the Missouri Compromise in Dred Scott v. Sanford 1857 after it had 
already been superseded by the Kansas-Nebraska Act is one particularly clear example.

10 Powe 2000; Rosen 2007.

11 Devins and Fisher 2015, 24-30.

12 Lemieux and Lovell 2009.

13 Mayhew 2004.

14 Lemieux and Lovell 2009.

15 Harper v. Virginia Board of Electors 1965. See Powe 2000,265 . The issue, of course, is complicated by the fact that it represented national majorities inviting the courts to pull recalcitrant states into line; such cases may reflect federal supremacy even if they do not represent judicial supremacy.

16 McGirr 2015.

17 Rosenberg 2008.

18 The tendency of the Court to bring state outliers into the national norms is a major theme of Powe's evaluation of the Warren Court; Powe 2000. See also Balkin 2011, 211-212.

19 See, e.g., AT\&T Mobility v. Concepcion, 563 U.S. 333 2011.

20 Engle v. Vitale 1962.

21 Goldsmith and Dillon 2015.

22 McCulloch v. Maryland 1819.

23 Whittington 2007, 59-61; Kramer 2004, 183-184.

24 It could be objected that a successful Senate filibuster would not reflect constitutional views and would be only "political," even if Republican legislators echoed the constitutional arguments being used in the litigation against the ACA. But both Jackson's bank veto and Marhsall's opinion in McCulloch were also surely a combination of constitutional and policy concerns. There is no clean way of separating "constitutionalism" and "politics" unless one makes an untenable a priori assumption that courts do only "law" and other political actors do only "politics."

25 See, e.g., Mouffe 2005.

26 For further discussion of Lincoln, Dred Scott, and judicial supremacy see Farber 2003, 178-179. Lincoln did not merely consider Dred Scott not binding in theory-he ignored its constitutional holdings upon assuming office.

27 All of these cases are discussed in detail as examples of sporadic "departmentalist" challenges to judicial supremacy on the part of reconstructive presidents by Whittington 2007.

28 See, e.g., Jackson 1960; Friedman 1998; Kramer 2004.

29 Perhaps the most conspicuous absences from the following list are the Supreme Court's landmark abortion cases Roe v. Wade 1973 and Planned Parenthood v. Casey 1992. I have attempted to demonstrate elsewhere that these cases do not meet the standards for judicial supremacy I have outlined above, and rather constitute cases of legislative default. See Lemieux and Lovell 2009.
30 See, e.g., Murphy 1963; Meernik and Ignagni 1997.

31 See, e.g., Burgess 1992; Devins 1996; Pickerill 2004.

32 See Zeisberg 2013.

33 For a detailed account of this process, see Clinton 1989.

34 Sloan and McKean 2010.

35 Goldstone 2008.

36 Burns 2010, 2, 31.

37 Cliff Sloan, "Is the Historic Case Marbury v.

Madison All It's Cracked Up To Be?," Slate.com, http://www.slate.com/id/2212517/entry/2212520/. Last accessed November 12, 2015.

38 Graber 2003, 610.

39 Douglas 2003.

40 Graber 1995, 1998, 2003; Klarman 2001; Levinson 2002, Ackerman 2007.

41 Graber 1999, 28.

42 Kramer 2004.

43 Marshall's opinion argues that when fulfilling its functions, the judiciary cannot apply an unconstitutional statute, but leaves entirely open the questions of how the coordinate branches should deal with unconstitutional actions and the normative weight other branches should give judicial interpretations in future cases. See also Tushnet 2000, 20-21; Nelson 2000, 231.

44 Whittington 2007, 9.

45 McCloskey 2000, 25-27.

46 See Lemieux 2003.

47 Goldstone 2008.

48 Stuart v. Laird, 1803.

49 Ackerman 2006, 211-212.

50 Cooper v. Aaron 1958.

51 See, e.g., Powe 2000, 160. In its reasoning, Cooper's assertions of judicial supremacy went well beyond Marbury's claim of the power of judicial review, and certainly the idea that judicial supremacy was immediately and "permanently" established by Marbury cannot be defended.

52 Friedman 2010, 245.

53 Tushnet 1994, 266.

54 Rosenberg 2008.

55 Klarman 2006, 389-468.

56 Signed by 101 members of Congress and issued in 1956, it read in part that "the original Constitution does not mention education. Neither does the 14th amendment nor any other amendment. The debates preceding the submission of the 14th amendment clearly show that there was no intent that it should affect the systems of education maintained by the States." http://georgiainfo.galileo.usg.edu/manifesto. htm, accessed September 24, 2015.

57 Carter 2000, 83-109; Klarman 2006, ch.7.

58 Balkin 2004.

59 Klarman 2006.

60 Carptenter 2003, 422. 
61 City of Boerne v. Flores 1997.

62 Employment Division v. Smith 1990. For a full account of the case and its implications, see Long 2000.

63 Sherbert v. Verner 1963. Under Sherbert, if a generally applicable law burdened practices based on sincere religious beliefs, the burden shifted to the state to show that the law advanced a compelling state interest that could not be advanced in a means involving less of a burden on religious practices. Technically, Smith did not overrule Sherbert, but strictly limited its applicability to future cases.

64 Section Five of the Fourteenth Amendment gives Congress the "power to enforce, by appropriate legislation, the provisions of this article."

65 Powe 2011, 315.

66 Ibid.

67 Tushnet 2006, 270.

68 See also, e.g., U.S. v. Morrison 2000, Board of Trustees of the University of Alabama v. Garrett 2001.

69 Ely 19-see, e.g., Spann 1993.

70 An interesting alternative that recognizes this problem is the "ratchet" theory suggested by Footnote Ten of Justice Brennan's opinion in Katzenbach v. Morgan 1966. Brennan's opinion implied that the Congress could expand protections for minority rights beyond what the Court required under its Fourteenth Amendment enforcement powers, but could not reduce them. For further discussion see Powe 2000, 262-265.

71 Burwell v. Hobby Lobby 2014.

72 See, e.g., South Dakota v. Dole 1987. The Court did, for the first time, rule in NFIB v. Sebelius 2012 that an act of Congress exceeded its constitutional authority under the spending power. However, at least on its face the restriction was purely formal. Congress could have created an expanded Medicaid program and present it to the states on a take-it-or-leave-it; they were just forbidden to do so by modifying the Medicaid program rather than replacing it. The decision, as it stands, should not prevent Congress from attempting to achieve substantive ends through conditional grants in all but a handful of cases.

73 Bush v. Gore 2000.

74 See esp. Scheppele 2001.

75 Raskin 2003, 12.

76 Hirschl 2007.

77 Balkin and Levinson 2001.

78 Posner 2001, 177.

79 Gillman 2003, 197.

80 Yates and Whitford 2002.

81 Shelby County v. Holder, 2013.

82 Northwest Austin v. Holder 2009.

83 Berman 2015, 86-96.

84 Plessy v. Ferguson 1896.
85 Section 2 states that in response to most state disenfranchisement of men 21 or older "the basis of representation therein shall be reduced in the proportion which the number of such male citizens shall bear to the whole number of male citizens twenty-one years of age in such state"; emphasis added.

86 Klarman 2006, 48-51.

87 See, e.g., Powe 2000; Ackerman 2014.

88 Lemieux and Lovell 2009.

89 Tushnet 2003.

\section{References}

Ackerman, Bruce. 2007. The Failure of the Founding Fathers: Jefferson, Marshall, and the Rise of Presidential Democracy. Cambridge, MA: Belknap.

- 2014. We the People, Volume 3: The Civil Rights Revolution. Cambridge, MA: Belknap.

Balkin, Jack M. 2004. "What Brown Teaches Us about Constitutional Theory.” Virginia Law Review 90(6): 1537-77. Belknap.

Balkin, Jack and Sanfod Levinson. 2001. "Understanding the Constitutional Revolution." Virginia Law Review 87(6): 1045-109.

Berman, Ari. 2015. Give Us the Ballot: The Modern Struggle for Voting Rights in America. New York: Farrar, Strauss and Giroux.

Burgess, Susan R. 1992. Contest for Constitutional Authority: The Abortion and War Powers Debates. Lawrence: University Press of Kansas.

Burns, James MacGregor. 2010. Packing the Court: The Rise of Judicial Power and the Coming Crisis of the Supreme Court. New York: Penguin.

Carpenter, Dale. 2003. "Judicial Supremacy and Its Discontents." Constitutional Commentary 20(2): 405-36.

Carter, Dan T. 2000. The Politics of Rage: George Wallace, the Origins of the New Conservatism, and the Transformation of American Politics. Baton Rouge: Louisiana State University Press.

Clinton, Robert L. 1989. Marbury v. Madison and Judicial Review. Lawrence: University Press of Kansas.

Devins, Neal. 1996. Shaping Constitutional Values: Elected Government, the Supreme Court, and the Abortion Debate. Baltimore: Johns Hopkins University Press.

Devins, Neal and Louis Fisher. 2015. The Democratic Constitution. 2d ed. New York: Oxford University Press.

Douglas, Davison. 2003. "The Rhetorical Uses of Marbury v. Madison: The Emergence of a "Great Case." Wake Forest Law Review 38: 375-414.

Ely, John H. 1980. Democracy and Distrust: A Theory of Judicial Review. Cambridge, MA: Harvard University Press. 
Farber, Daniel A. 2003. Lincoln's Constitution. Chicago: University of Chicago Press.

Fisher, Louis. 1993. "One of the Guardians Some of the Time." In Is the Supreme Court the Guardian of the Constitution?, ed. Robert A. Licht. Washington, DC: American Enterprise Institute.

Friedman, Barry. 1998. "The History of the Countermajoritarian Difficulty, Part One: The Road to Judicial Supremacy." New York University Law Review 73(2): $333-433$.

2010. The Will of the People: How Public Opinion Has Influenced the Supreme Court and Shaped the Meaning of the Constitution. New York: Farrar, Straus and Giroux.

Friedman, Barry and Erin F. Delaney. 2011. "Becoming Supreme: The Federal Foundation of Judicial Supremacy." Columbia Law Review 111(6): 1137-93.

Gibson, James L. and Gregory A. Caldeira. 2009. Citizens, Courts, and Confirmations: Positivity Theory and the Judgments of the American People. Princeton, NJ: Princeton University Press.

- 2003. The Votes That Counted: How the Court Decided the 2000 Presidential Election. 1st ed. Chicago: University of Chicago Press.

Goldsmith, Lauren Maisel and James R. Dillon. 2015. "The Hollowed Hope: The School Prayer Cases and Social Change." St. Louis University Law Journal 59: 409-60.

Goldstone, Lawrence. 2008. The Activist: John Marshall, Marbury v. Madison, and the Myth of Judicial Review. 1st ed. New York: Walker.

Graber, Mark. 1993. “The Nonmajoritarian Difficulty: Legislative Deference to the Judiciary." Studies in American Political Development 7(1): 35-73. 1995. "The Passive-Aggressive Virtues: Cohen v. Virginia and the Problematic Establishment of Judicial Power." Constitutional Commentary 12: 67.

. 1998. "Establishing Judicial Review? Schooner Peggy and the Early Marshall Court." Political Research Quarterly 51: 221

2003. "Establishing Judicial Review: Marbury and the Judicial Act of 1789." Tulsa Law Review 38: $609-50$.

2013. A New Introduction to American

Constitutionalism. New York: Oxford University Press.

Hirschl, Ran. 2007. Towards Juristocracy: The Origins and Consequences of the New Constitutionalism. Cambridge, MA: Harvard University Press.

Jackson, Robert Houghwout. 1960. The Struggle for Judicial Supremacy: A Study of a Crisis in American Power. New York: Vintage Books.

Klarman, Michael J. 2001. "How Great Were the 'Great' Marshall Court Decisions?” Virginia Law Review 87(6): $1111-84$.

2006. From Jim Crow to Civil Rights: The Supreme Court and the Struggle for Racial Equality. New York: Oxford University Press.
Kramer, Larry D. 2004. "Understanding Marbury v. Madison." Proceedings of the American Philosophical Society 148(1): 14-26.

Lemieux, Scott E. 2003. "The Exception That Defines the Rule: Marshall's Marbury Strategy and the Development of Supreme Court Doctrine." Journal of Supreme Court History 28(2): 197-211.

Lemieux, Scott E. and George Lovell. 2008. "Understanding the Impact and Visibility of Ideological Change on the Supreme Court." In Constitutional Politics in a Conservative Era (Studies in Law, Politics and Society, Volume 44), ed. Austin Sarat. Bradford: Emerald Group Publishing.

— 2009. "Legislative Defaults: Interbranch Power Sharing and Abortion Politics." Polity 42(2): 210-43.

Lemieux, Scott E. and David J. Watkins. 2008. "Beyond the 'Countermajoritarian Difficulty': Lessons from Contemporary Democratic Theory.” Polity 41(1): 30-62.

Levinson, Sanford. 2002. "Bush v. Gore and the French Revolution: A Tentatove List of Some Early Lessons." Law \& Contemporary Problems 65(3): 7-39.

Long, Carolyn N. 2000. Religious Freedom and Indian Rights: The Case of Oregon v. Smith. Lawrence: University Press of Kansas.

Lovell, George I. 2003. Legislative Deferrals: Statutory Ambiguity, Judicial Power, and American Democracy. Cambridge: Cambridge University Press.

Mayhew, David R. 2004. Congress: The Electoral Connection. 2d ed. New Haven, CT: Yale University Press.

McCloskey, Robert G. 2000. The American Supreme Court. Chicago: University of Chicago Press.

McGirr, Lisa 2015. The War on Alcohol: Prohibition and the Rise of the American State. New York: W.W. Norton.

Meernik, James and Joseph Ignagni. 1997, "Judicial Review and Coordinate Construction of the Constitution." American Journal of Political Science 41: 2.

Mouffe, Chantal. 2005. On the Political. London: Routledge.

Murphy, Walter F. 1962. Congress and the Court. Chicago: University of Chicago Press.

Nelson, William E. 2000. Marbury v. Madison: The Origins and Legacy of Judicial Review. Lawrence: University Press of Kansas.

Pickerill, J. Mitchell. 2004. Constitutional Deliberation in Congress: The Impact of Judicial Review in a Separated System. Durham, NC: Duke University Press.

Posner, Richard A. 2001. Breaking the Deadlock: The 2000 Election, the Constitution, and the Courts. Princeton, NJ: Princeton University Press.

Powe, Lucas. 2000. The Warren Court and American Politics. Cambridge, MA: Belknap.

2011. The Supreme Court and the American Elite, 1789-2008. Cambridge, MA: Harvard University Press, 2011. 
Raskin, Jamin B. 2003. Overruling Democracy: The Supreme Court Vs. the American People. New York: Psychology Press.

Rosen, Jeffrey. 2007. The Most Democratic Branch: How the Courts Serve America. New York: Oxford University Press.

Rosenberg, Gerald N. 2008. The Hollow Hope: Can Courts Bring About Social Change? 2nd ed. Chicago: University of Chicago Press.

Scheppele, Kim Lane. 2001. "When the Law Doesn't Count: The 2000 Election and the Failure of the Rule of Law."

University of Pennsylvania Law Review 149(5): 1361-437.

Sloan, Cliff and David McKean. 2010. The Great Decision: Jefferson, Adams, Marshall, and the Battle for the Supreme Court. New York: PublicAffairs.

Spann, Girardeau. 1994. Race against the Court: The Supreme Court and Minorities in Contemporary America. New York: New York University Press.

Tushnet, Mark. 1994. Making Civil Rights Law: Thurgood Marshall and the Supreme Court, 1936-1961. New York: Oxford University Press.
2000. Taking the Constitution Away from

the Courts. Princeton, NJ: Princeton University Press. . 2003. The New Constitutional Order. Princeton,

NJ: Princeton University Press.

. 2006. "The Supreme Court and the National

Political Order: Collaboration and Confrontation.” In

The Supreme Court and American Political

Development, ed. Ronald Kahn. Lawrence:

University of Kansas Press.

Whittington, Keith E. 2007. Political Foundations of Judicial Supremacy: The Presidency, the Supreme Court, and Constitutional Leadership in U.S. History. Princeton, NJ: Princeton University Press.

Yates, Jeff and Andrew Whitford. 2002. "The Presidency and the Supreme Court after Bush v. Gore: Implications for Institutional Legitimacy and Effectiveness." Stanford Law \& Policy Review 13(1): 101-20.

Zeisberg, Mariah. 2013. War Powers: The Politics of Constitutional Authority. Princeton, NJ: Princeton University Press. 